\title{
Randomized Phase II Trial of Seribantumab in Combination with Erlotinib in Patients with EGFR Wild-Type Non-Small Cell Lung Cancer
}

\author{
Lecia V. Sequist, ${ }^{a}$ Jhanelle Elaine Gray, ${ }^{b}$ Wael A. Harb, ${ }^{c}$ Ariel Lopez-Chavez, ${ }^{d}$ Robert C. Doebele, ${ }^{e}$ Manuel R. Modiano, ${ }^{f}$ \\ David Michael Jackman, ${ }^{g}$ Maria Quintos Baggstrom, ${ }^{h}$ Akin Atmaca, ${ }^{i}$ Enriqueta Felip, ${ }^{j}$ Mariano Provencio, ${ }^{k}$ Manuel Cobo, \\ Bambang Adiwijaya, ${ }^{m}$ Geoffrey Kuesters, ${ }^{m}$ Walid S. Kamoun, ${ }^{m}$ Karen Andreas, ${ }^{m}$ J. Marc Pipas, ${ }^{m}$ Sergio Santillana, ${ }^{m}$ \\ Byoung Chul Cho, ${ }^{n}$ Keunchil Park, ${ }^{\circ}$ Frances A. Shepherd ${ }^{p}$ \\ ${ }^{a}$ Massachusetts General Hospital, Boston, Massachusetts, USA; ${ }^{b} \mathrm{H}$. Lee Moffitt Cancer Center \& Research Institute, Tampa, Florida, \\ USA; ${ }^{C}$ Horizon Oncology Center, Lafayette, Indiana, USA; ${ }^{d}$ Knight Cancer Institute, Oregon Health and Science University, Portland, \\ Oregon, USA; ${ }^{~}$ University of Colorado Cancer Center, Aurora, Colorado, USA; ${ }^{\mathrm{f}}$ Arizona Clinical Research Center, Tucson, Arizona, USA; \\ ${ }^{g}$ Dana-Farber Cancer Institute, Boston, Massachusetts, USA; ${ }^{h}$ Division of Oncology, Washington University School of Medicine, St. \\ Louis, Missouri, USA; 'Department of Hematology and Oncology, Institute of Clinical Research at Krankenhaus Nordwest, UCT- \\ University Cancer Center, Frankfurt, Germany; ${ }^{j}$ Vall d’Hebron University Hospital, Barcelona, Spain; ${ }^{k}$ Hospital Universitario Puerta de \\ Hierro Majadahonda, Madrid, Spain; 'Hospital Regional Universitario Málaga, Instituto de Investigación Biomédica de Málaga, Málaga, \\ Spain; ${ }^{m}$ Merrimack Pharmaceuticals, Inc., Cambridge, Massachusetts, USA; ${ }^{\text {n} Y o n s e i ~ U n i v e r s i t y ~ C o l l e g e ~ o f ~ M e d i c i n e, ~ S e o u l, ~ S o u t h ~}$ \\ Korea; ${ }^{\circ}$ Department of Medicine, Division of Hematology-Oncology, Samsung Medical Center, Sungkyunkwan University School of

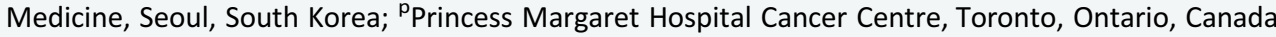 \\ Disclosures of potential conflicts of interest may be found at the end of this article.
}

Key Words. Antibody • Heregulin • Translational - Targeted therapy • Biomarkers • Seribantumab • HER3/ErbB3

AbSTRACT

Background. Seribantumab (MM-121) is a fully human IgG2 monoclonal antibody that binds to human epidermal growth factor receptor 3 (HER3/ErbB3) to block heregulin (HRG/ $N R G)$-mediated ErbB3 signaling and induce receptor downregulation. This open-label, randomized phase $1 / 2$ study evaluated safety and efficacy of seribantumab plus erlotinib in advanced non-small cell lung cancer (NSCLC). Here, we report the activity of seribantumab plus erlotinib, versus erlotinib alone, in patients with EGFR wild-type tumors and describe the potential predictive power of HRG.

Materials and Methods. Patients with EGFR wild-type NSCLC were assigned randomly to receive seribantumab + erlotinib or erlotinib alone. Patients underwent pretreatment core needle biopsy and archived tumor samples were collected to support prespecified biomarker analyses.

Results. One hundred twenty-nine patients received seribantumab + erlotinib ( $n=85$ ) or erlotinib alone $(n=44)$. Median estimated progression-free survival (PFS) in the unselected intent-to-treat (ITT) population was 8.1 and 7.7 weeks in the experimental and control arm, respectively (hazard ratio $[\mathrm{HR}], 0.822 ; 95 \%$ confidence interval [Cl], 0.37-1.828; $p=0.63$ ), and median estimated overall survival was 27.3 and 40.3 weeks in the experimental and control arm, respectively (HR, 1.395; 95\% Cl, 0.846 to $2.301 ; p=.1898$ ) In patients whose tumors had detectable HRG mRNA expression, treatment benefit was observed in the seribantumab + erlotinib combination ( $\mathrm{HR}, 0.35 ; 95 \% \mathrm{Cl}, 0.16-0.76 ; p=.008)$. In contrast, in patients whose tumors were HRG negative, the HR was $2.15(95 \% \mathrm{Cl}, 0.97-4.76 ; p=.059$, HRG-bytreatment interaction, $p$ value $=.0016)$.

Conclusion. The addition of seribantumab to erlotinib did not result in improved PFS in unselected patients. However, predefined retrospective exploratory analyses suggest that detectable HRG mRNA levels identified patients who might benefit from seribantumab. An ongoing clinical trial of seribantumab, in combination with docetaxel, is underway in patients with advanced NSCLC and high HRG mRNA expression (NCT02387216). The Oncologist 2019;24:1095-1102

Implications for Practice: The poor prognosis of patients with non-small cell lung cancer (NSCLC) underscores the need for more effective treatment options, highlighting the unmet medical need in this patient population. The results of this study show that a novel biomarker, heregulin, may help to identify patients with advanced NSCLC who could benefit from treatment

Correspondence: Lecia V. Sequist, M.D., Massachusetts General Hospital, Department of Hematology and Oncology, 55 Fruit Street, Boston, Massachusetts 02114-2696, USA. Telephone: 617-724-4000; e-mail: LVSEQUIST@PARTNERS.ORG Received October 15, 2018; accepted for publication February 8, 2019; published Online First on April 12, 2019. http://dx.doi.org/10.1634/theoncologist.2018-0695 
with seribantumab. On the basis of the observed safety profile and promising clinical efficacy, a prospective, randomized, open-label, international, multicenter phase II trial (SHERLOC, NCT02387216) is under way to investigate the efficacy and safety of seribantumab in combination with docetaxel in patients with heregulin-positive advanced adenocarcinoma.

\section{INTRODUCTION}

Treatment for non-small cell lung cancer (NSCLC) has evolved significantly over the last decade with the approval of several targeted and immune checkpoint therapies for specific patient subpopulations. For patients with advanced NSCLC harboring an activating mutation in the tyrosine kinase (TK) domain of the epidermal growth factor receptor (EGFR) or who have activating rearrangements in anaplastic lymphoma kinase $(A L K)$ or ROS-1, targeted treatment is available in the form of small molecule TK inhibitors (TKIs) [1]. Despite clinical benefit from TKIs, nearly all patients develop disease progression through various acquired resistance mechanisms. Developing drugs that effectively combat resistance mechanisms is of high interest and could potentially improve patient outcome.

One of the common mechanisms of resistance to targeted therapy is activation of compensatory signaling pathways that mediate antiapoptotic or prosurvival effects, protecting cancer cells from the effects of the therapy. Notably, through the activation of the PI3K/AKT pathway, heregulin (HRG)-driven ErbB3 signaling mediates resistance to a broad range of targeted and cytotoxic therapies [2, 3].

HRG binding to HER3 results in heterodimerization preferentially with HER2. HER3-mediated signaling involves the $\mathrm{PI} 3 \mathrm{~K} / \mathrm{AKT} / \mathrm{mTOR}$ and other pathways, including MAPK/ERK and JAK/STAT, leading to cancer cells proliferation, migration and differentiation. HRG/HER3 pathway activation is associated with worse clinical outcome [4].

In NSCLC, ErbB3 promotes cell proliferation and confers survival to cells treated with EGFR targeted therapies as well as various chemotherapies $[3,5,6]$. In addition, heregulin is commonly expressed in NSCLC [7]. Rates of HRG expression vary by tumor histology and range from $45 \%$ in adenocarcinoma to $87 \%$ in squamous cell lung cancer [8]. These data suggest that HRG/ErbB3 blockade may increase sensitivity to targeted therapy in patients in whom the HRG/EbB3 pathway is activated [5].

Seribantumab (MM-121; Merrimack Pharmaceuticals, Inc., Cambridge, MA) is a fully human immunoglobulin $\mathrm{G} 2$ antibody that targets ErbB3 by blocking HRG binding and downregulating the receptor $[3,5,9,10]$. Seribantumab exhibits additive and synergistic effects on tumor growth inhibition in tumor xenograft models of lung cancer and triple negative breast cancer in combination with cetuximab and erlotinib [5]. We completed a phase $1 / 2$ study assessing the combination of seribantumab and erlotinib in various populations of patients with NSCLC. The phase 1 portion of the study comprised 33 patients, including 21 with adenocarcinoma, all of whom were treated with erlotinib plus seribantumab $[9,11]$. No maximum tolerated dose was identified, and the adverse event profile was similar to that of erlotinib alone. The recommend phase II dose and schedule was erlotinib $100 \mathrm{mg}$ daily with seribantumab $40 \mathrm{mg} / \mathrm{kg}$ intravenous (IV) loading dose, then $20 \mathrm{mg} / \mathrm{kg}$ IV every other week. The phase II portion of the trial enrolled three groups of patients, including patients with EGFR wild-type tumors who had not previously received prior EGFR TKI targeted therapy (group A), patients with EGFR activating mutations who had no prior EGFR TKI targeted therapy (group $B)$, and patients whose tumors were resistant to EGFR targeted therapies (group C). Here, we report results of the phase II trial, group $\mathrm{A}$, consisting of patients with confirmed EGFR wild-type tumors representing the largest subgroup within the trial.

\section{Materials And Methods}

\section{Study Design}

This was a multicenter, open-label phase $1 / 2$ study (NCT00994123). The phase I portion of the study aimed to identify the maximum tolerated dose of seribantumab plus erlotinib and to optimize the dosing schedule. The phase II portion was an open-label randomized study of seribantumab plus erlotinib (experimental arm) versus erlotinib alone (control arm) in three populations of patients with advanced NSCLC: group A consisted of EGFR wild-type patients who had failed prior systemic therapy, group B was TKI-naive patients harboring an EGFR activating mutation, and group $\mathrm{C}$ was a single arm cohort of EGFR-mutant patients with acquired resistance to treatment with single-agent EGFR-TKI [9].

In group A (EGFR wild-type tumors), patients were assigned randomly in a 2:1 ratio to receive seribantumab plus erlotinib or erlotinib alone with two stratification factors: Eastern Cooperative Oncology Group (ECOG) performance status (0-1 vs. 2 ) and number of prior therapies (1-2 vs. $\geq 3$ ). Seribantumab was administered with a $40 \mathrm{mg} / \mathrm{kg}$ IV loading dose, then $20 \mathrm{mg} / \mathrm{kg}$ IV every other week. The erlotinib dose was $100 \mathrm{mg}$ per day in combination with seribantumab and $150 \mathrm{mg}$ per day in the erlotinib only arm. Response to treatment was assessed radiographically every 8 weeks. Study therapy was administered until progression or elective discontinuation for side effects or any other reason. After discontinuation from the study, survival data were collected every 4 months from the date of the 30-day follow-up visit.

The primary endpoint was investigator-assessed progression-free survival (PFS) assessed by RECIST version 1.1. [12]. Secondary objectives included overall survival (OS) and objective response rate (ORR), further characterization of the safety profile of seribantumab, and examination of predictive biomarkers.

All patients provided written informed consent, and local institutional review boards and/or ethics committees approved the study protocol. The study was supported financially by Merrimack Pharmaceuticals, Inc. (Cambridge, MA) and Sanofi S.A. (Paris, France).

\section{Patients}

Eligible patients were adults with histologically confirmed advanced NSCLC with confirmed EGFR wild-type status, with 


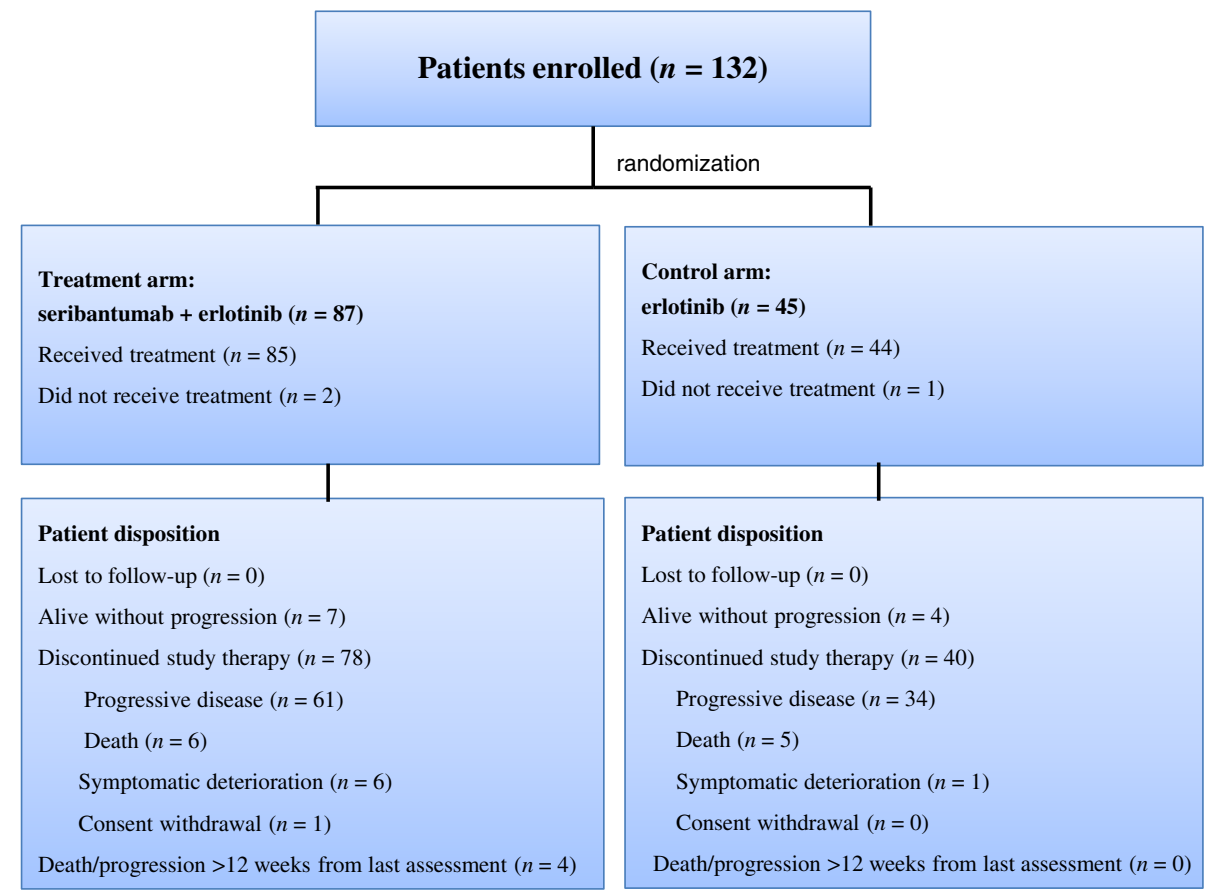

Figure 1. CONSORT diagram. Data as per data cut-off date, October 7, 2013.

an exception for squamous histology of unknown EGFR status. Eligibility criteria included ECOG performance status 0-2 and adequate hematopoietic, renal, and hepatic functions. Patients could not have received prior EGFR TKI targeted therapies but must have progressed following treatment with at least one prior chemotherapy-containing regimen. All patients underwent a mandatory pretreatment core needle biopsy to provide fresh tumor samples for biomarker analyses. Archival tumor samples were also submitted, as available.

\section{Biomarker Analysis}

Biomarker analyses were performed on formalin-fixed, paraffin-embedded sections from the pretreatment biopsies. Given evolving data from parallel trials in breast and ovarian cancer, predefined biomarker analysis focused specifically on HRG mRNA expression [10, 13]. HRG mRNA expression levels were analyzed using a chromogenic-based RNA in situ hybridization (RNA-ISH) assay developed by Advanced Cell Diagnostics (Newark, CA). Slides were evaluated by a board-certified pathologist as follows: (a) cancer cell content assessment, excluding any slides with $<20 \%$ cancer cells; (b) cancer cells were scored as follows: score $0=$ 0 RNA-ISH dots, score 1 = 1-3 dots, score 2 = 4-9 dots, score $3=10-15$, score $4=\geq 16$ dots; (c) overall HRG expression was computed as the highest score in at least $10 \%$ of tumor cells.

\section{Statistical Considerations}

The primary efficacy PFS endpoint was based on the intentto-treat (ITT) populations, with PFS defined as the time from date of randomization to disease progression or death. Tumor assessment was done by investigator in accordance with RECIST version 1.1. Safety analyses were performed on the safety population (all patients who received at least one dose of study drug), and adverse events (AEs) were graded according to National Cancer Institute Common Terminology
Criteria for Advanced Events (version 4.0) and MedDRA system organ class.

A total of 102 PFS events were needed to detect a $50 \%$ reduction in the hazard ratio (HR) of 0.5 in the experimental arm relative to the control arm with $90 \%$ power, using a logrank test at an overall one-sided 0.025 level. The primary efficacy analysis was performed using a stratified log-rank test. Survival analyses were performed using Kaplan-Meier estimates, and HR estimates were calculated using a stratified Cox proportional hazards model.

All efficacy biomarker subgroup analyses (HRG-positive and HRG-negative) were performed on the biomarker population, a subset of the safety population which included all patients with available HRG RNA-ISH data, using an unstratified Cox proportional hazard model. Sensitivity analyses of the robustness of the biomarker results were performed by factoring clinical covariates into a multivariate Cox proportional hazard model of PFS, with treatment-bybiomarker status as factors and clinical covariates as additive factors or as stratification factors.

\section{RESULTS}

\section{Study Population}

A total of 132 patients from North America, Asia, and Europe were enrolled between November 2012 and March 2013 to the phase II study group $A$ and randomized to receive seribantumab plus erlotinib $(n=85)$ or erlotinib alone $(n=44$; Fig. 1). Three randomized patients (two in the experimental treatment arm and one in the control arm) did not receive the study drug: two patients because of death and 1 because of the consent withdrawal. The patient population had a median age of 64 years, with $59 \%$ male and $87 \%$ white, $84 \%$ current or former smokers, and $67 \%$ with adenocarcinoma tumors (Table 1). Treatment arms were well balanced. 
Table 1. Patients demographic and clinical characteristics

\begin{tabular}{|c|c|c|c|}
\hline Characteristics & $\begin{array}{l}\text { All patients, } \\
n=129\end{array}$ & $\begin{array}{l}\text { Seribantumab } 20 \mathrm{mg} / \mathrm{kg} \\
\text { QOW + erlotinib } \\
100 \mathrm{mg} \text { QD, } n=85\end{array}$ & $\begin{array}{l}\text { Erlotinib } \\
150 \mathrm{mg} \text { QD, } \\
n=44\end{array}$ \\
\hline Age, median (range), yr & $64(35-85)$ & $65(35-85)$ & $64(41-80)$ \\
\hline \multicolumn{4}{|l|}{ Gender, $n(\%)$} \\
\hline Male & 77 & $50(58.8)$ & $27(61.4)$ \\
\hline Female & 52 & $35(41.2)$ & $17(38.6)$ \\
\hline \multicolumn{4}{|l|}{ Race, $n(\%)$} \\
\hline White & 110 & $74(87.1)$ & $36(81.8)$ \\
\hline Black/African American & 5 & $3(3.5)$ & $2(4.5)$ \\
\hline American Indian or Alaska native & 1 & $1(1.2)$ & $0(0)$ \\
\hline Asian & 13 & $7(8.2)$ & $6(13.6)$ \\
\hline \multicolumn{4}{|l|}{ Smoking history, $n$ (\%) } \\
\hline Current smoker & 22 & $17(20.0)$ & $5(11.4)$ \\
\hline Former smoker & 80 & $54(63.5)$ & $26(59.1)$ \\
\hline Never-smoker & 24 & $12(14.1)$ & $12(27.3)$ \\
\hline History not known & 3 & $2(2.4)$ & $1(2.2)$ \\
\hline \multicolumn{4}{|l|}{ Tumor histology, $n$ (\%) } \\
\hline Adenocarcinoma & 92 & $57(67.1)$ & $35(79.5)$ \\
\hline Squamous cell carcinoma & 26 & $22(25.9)$ & $4(9.1)$ \\
\hline Adenosquamous carcinoma & 3 & $1(1.2)$ & $2(4.5)$ \\
\hline Large cell carcinoma & 2 & $1(1.2)$ & $1(2.3)$ \\
\hline Other or unclassified carcinoma & 6 & $4(4.8)$ & $2(4.5)$ \\
\hline \multicolumn{4}{|l|}{ Metastatic status, $n(\%)$} \\
\hline Brain metastasis & 20 & $12(14.1)$ & $8(18.2)$ \\
\hline Other & 95 & $64(75.3)$ & $31(70.5)$ \\
\hline Not done & 14 & $9(10.6)$ & $5(11.4)$ \\
\hline \multicolumn{4}{|l|}{ Chemotherapy naive, $n$ (\%) } \\
\hline Yes & 2 & $2(2.4)$ & $0(0)$ \\
\hline No & 127 & $83(97.6)$ & $44(100)$ \\
\hline
\end{tabular}

Abbreviations: QD, one per day; QOW, every other week.

\section{Safety}

Patients in each treatment arm completed up to 13 cycles of treatment. The median cumulative dose was $5,988 \mathrm{mg}$ (range 1,328-46,145) and 12,625 mg (range 800-73,000) for seribantumab and erlotinib, respectively.

All patients experienced at least one treatment-emergent adverse event (TEAE). The most common adverse events of any grade were diarrhea, rash, decreased appetite, fatigue, and nausea in both arms; however, these events occurred more frequently in patients who received seribantumab plus erlotinib versus erlotinib alone (Table 2 ). Overall, there was no meaningful difference in TEAEs grade 3 or higher between the two arms except diarrhea, which was more frequently observed in the experimental treatment arm versus control.

A total of 77 (59.7\%) patients died during the study, with 30 (23.3\%) patients experiencing AEs leading to death; however, none of these events was considered to be related to seribantumab. Only two $(2.4 \%)$ and two (4.5\%) patients in the experimental treatment and control arm, respectively, experienced TEAEs that led to the discontinuation of the study drug. Overall, the observed safety profile was consistent with the expected toxicities for seribantumab and appeared manageable.

\section{Efficacy}

The data cutoff for the primary analysis was October 7, 2013, with a median follow-up of 6.3 months. The estimated median PFS among the ITT population was 8.1 weeks in the experimental arm and 7.7 weeks in the control arm (HR, 0.816; 95\% confidence interval [Cl], 0.552-1.207; stratified log-rank $p=.3084$; Fig. 2). Because there was no statistically significant PFS difference between arms, the study did not meet its primary endpoint.

One complete response (1.2\%) and four partial responses (4.7\%) were seen in the experimental arm. No complete responses and two (4.5\%) partial responses were seen in the control arm. Stable disease was observed in eight patients $(34.8 \%)$ in the experimental treatment arm and in one patient (7.1\%) in the control arm. Median OS was 27.3 weeks in the experimental arm compared with 40.3 weeks in the control arm (HR, 1.395; 95\% Cl, 0.846-2.301; stratified log-rank $p=$ .1898; online supplemental Fig. 1, online supplemental Table 1).

\section{Biomarker Analyses}

Of 129 patients in safety population, biomarker analyses were conducted for HRG mRNA expression by RNA-ISH 
Table 2. Treatment emergent adverse events occurring in $\geq 10 \%$ of patients (safety population)

\begin{tabular}{|c|c|c|c|c|}
\hline \multirow[b]{2}{*}{ Preferred term, AE } & \multicolumn{2}{|c|}{$\begin{array}{c}\text { Seribantumab } 20 \mathrm{mg} / \mathrm{kg} \\
\text { QOW + erlotinib } 100 \mathrm{mg} \text { QD }(n=85), n(\%)\end{array}$} & \multicolumn{2}{|c|}{$\begin{array}{l}\text { Erlotinib } 150 \mathrm{mg} \\
\text { QD }(n=44), n(\%)\end{array}$} \\
\hline & All Grade & Grade $\geq 3$ & All grade & Grade $\geq 3$ \\
\hline At least $1 \mathrm{AE}$ & $85(100)$ & $49(57.6)$ & $44(100)$ & $25(56.8)$ \\
\hline Diarrhea & $59(69.4)$ & $7(8.2)$ & $27(61.4)$ & $2(4.5)$ \\
\hline Rash & $46(54.1)$ & $3(3.5)$ & $21(47.7)$ & $3(6.8)$ \\
\hline Decreased appetite & $37(43.5)$ & $1(3.3)$ & $16(36.4)$ & $0(0)$ \\
\hline Fatigue & $31(36.5)$ & $1(1.2)$ & $13(29.5)$ & $0(0)$ \\
\hline Nausea & $29(34.1)$ & $1(1.2)$ & $14(31.8)$ & $0(0)$ \\
\hline Dry skin & $28(32.9)$ & $1(1.2)$ & $11(25.0)$ & $0(0)$ \\
\hline Weight decreased & $27(31.8)$ & $0(0)$ & $11(25.0)$ & $0(0)$ \\
\hline Dyspnea & $22(25.9)$ & 9 (10.6) & $9(20.5)$ & $6(13.6)$ \\
\hline Vomiting & $19(22.4)$ & $2(2.4)$ & $11(25.0)$ & $1(2.3)$ \\
\hline Dermatitis acneiform & $14(16.5)$ & $0(0)$ & $12(27.3)$ & $1(2.3)$ \\
\hline Stomatitis & $20(23.5)$ & $0(0)$ & $5(11.4)$ & $0(0)$ \\
\hline Cough & $16(18.8)$ & $0(0)$ & $6(13.6)$ & $0(0)$ \\
\hline Pruritis & $10(11.8)$ & $1(1.2)$ & $10(22.7)$ & $1(2.3)$ \\
\hline Back pain & $15(17.6)$ & $2(2.4)$ & $4(9.1)$ & $0(0)$ \\
\hline Dizziness & 11 (12.9) & $1(1.2)$ & $8(18.2)$ & $0(0)$ \\
\hline Constipation & $10(11.8)$ & $0(0)$ & 7 (15.9) & $0(0)$ \\
\hline Hypokalemia & $14(16.5)$ & $4(4.7)$ & $3(6.8)$ & $0(0)$ \\
\hline Dysgeusia & $14(16.5)$ & $0(0)$ & $1(2.3)$ & $0(0)$ \\
\hline Anemia & 9 (10.6) & $2(2.4)$ & $4(9.1)$ & $0(0)$ \\
\hline Arthralgia & 9 (10.6) & $2(2.4)$ & $4(9.1)$ & $0(0)$ \\
\hline Asthenia & $7(8.2)$ & $0(0)$ & $6(13.6)$ & $0(0)$ \\
\hline Pyrexia & $6(7.1)$ & $0(0)$ & 7 (15.9) & $0(0)$ \\
\hline
\end{tabular}

Abbreviations: $A E$, adverse event; $Q D$, one per day; QOW, every other week.

measured on pretreatment biopsies in 69 patients (43 in the treatment arm and 26 in the control arm) who had tissue samples adequate for the analysis. HRG mRNA measured on archival tissues was available only in five samples.

Overall, patients with evaluable HRG RNA-ISH had a PFS hazard ratio of $1.02(95 \% \mathrm{Cl}, 0.61-1.71)$, comparable to that of the ITT population (Fig. 2A). The prognostic effect of HRG was assessed by evaluating the PFS by HRG RNA-ISH level within the control (erlotinib alone) arm (Fig. 2B). HRGpositive status, defined as detectable level (score $\geq 1$ ), was associated with an increased risk of progression compared with HRG-negative, with an unstratified hazard ratio of 3.07 (95\% Cl, 1.19-7.91). The predictive effect of HRG with respect to seribantumab therapy was assessed by evaluating the PFS by treatment arms within each of the HRG groups (Fig. 2C, 2D). In the HRG-positive population, the addition of seribantumab to erlotinib reduced the risk of progression, with an unstratified $\mathrm{HR}$ of $0.35(95 \% \mathrm{Cl}, 0.16-0.76)$. In the HRG-negative population, treatment with seribantumab plus erlotinib increased the risk of progression, as compared with treatment with erlotinib alone, with an unstratified HR of 2.15 (95\% Cl, 0.97-4.76; Table 3). The estimated HRG-bytreatment interaction $p$ value was .0016 . Assessment of various cut-points for patients with HRG-positive tumors showed no significant difference in the estimated hazard ratios between HRG score 1-2 and HRG score $>2$ (supplemental online Fig. 2).

Sensitivity analysis was performed by evaluating a multivariate regression to account for potential imbalances by including age, sex, histology, smoking status, weight, and number of prior therapies. The results indicate robustness in the hazard ratio estimates of the HRG-positive subpopulation, with an estimated value similar to those observed from the unstratified analysis ( $\mathrm{HR}, 0.38 ; 95 \% \mathrm{Cl}, 0.16-0.89$ ).

\section{Discussion}

In this randomized phase II study of seribantumab plus erlotinib compared with erlotinib alone in patients with NSCLC with wild-type EGFR tumors, there was no observed improvement in PFS. However, in a prespecified retrospective subgroup analysis, a potential benefit was observed in patients whose tumors were positive for HRG overexpression as assessed by RNA-ISH. HRG plays a central role in regulating growth, invasion, angiogenesis, and cell survival in many tumor types, either through expression or activation of an autocrine or paracrine loop [14]. Seribantumab was developed as a cancer therapeutic to block HRG binding to ErbB3 receptor and induce receptor downregulation. This inhibition blocks HRG-ErbB3 dimerization with other ErbB family members, primarily ErbB2, and prevents activating signaling 

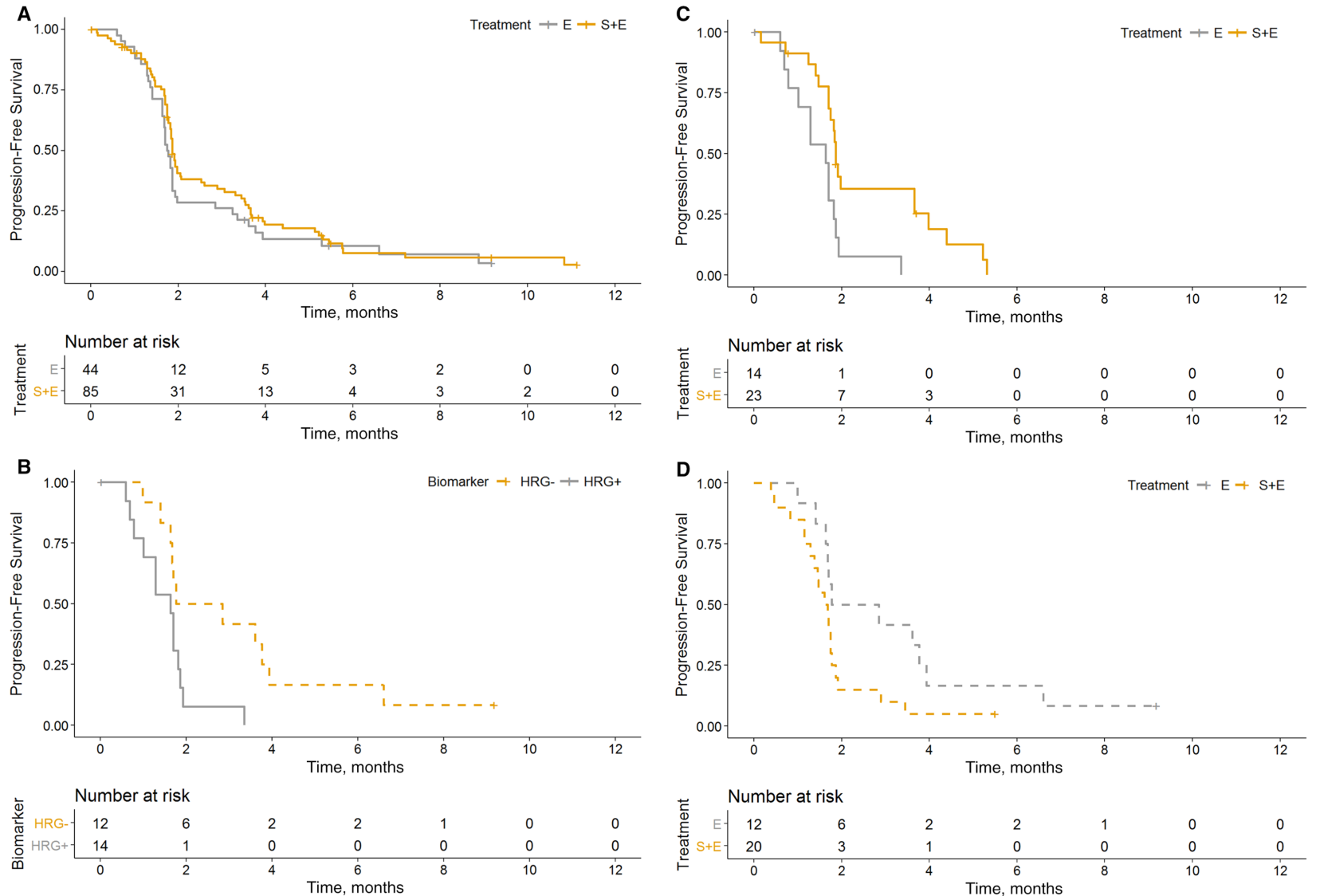

Figure 2. Kaplan-Meier estimated progression-free survival (PFS) curves by biomarker status. (A): PFS by treatment arm in the biomarker population. (B): PFS by HRG status in the control arm patients. (C): PFS by treatment arms for the HRG-positive patients. (D): PFS by treatment arm for the HRG-negative patients.

Abbreviations: $E$, erlotinib arm; HRG, heregulin; $S+E$, seribantumab + erlotinib arm.

Table 3. Summary statistics of PFS by biomarker subgroups

\begin{tabular}{|c|c|c|c|c|c|c|}
\hline \multirow[b]{2}{*}{ Group } & \multirow[b]{2}{*}{ Strata } & \multirow[b]{2}{*}{$\begin{array}{l}\text { Events, } \\
n(\%)\end{array}$} & \multirow[b]{2}{*}{$\begin{array}{l}\text { PFS time, median } \\
(95 \% \mathrm{Cl}), \mathrm{mo}\end{array}$} & \multicolumn{3}{|c|}{ Hazard ratio $^{a}$} \\
\hline & & & & $\begin{array}{l}\text { Point estimate } \\
(95 \% \mathrm{Cl})\end{array}$ & $\begin{array}{l}\text { Wald } \\
p \text { value }\end{array}$ & $\begin{array}{l}\text { Log-rank } \\
p \text { value }\end{array}$ \\
\hline \multirow[t]{2}{*}{ Unselected } & Treatment $=\mathrm{E}$ & $44(89)$ & $1.76(1.63-1.86)$ & & & \\
\hline & Treatment $=\mathrm{S}+\mathrm{E}$ & $85(85)$ & $1.86(1.77-2.05)$ & $0.81(0.55-1.20)$ & .290 & .295 \\
\hline \multirow[t]{2}{*}{ Control arm } & Biomarker status $=$ HRG-negative & $12(92)$ & $2.31(1.40-3.93)$ & & & \\
\hline & Biomarker status = HRG-positive & $14(93)$ & $1.63(0.78-1.82)$ & 3.07 (1.19-7.91) & .020 & .016 \\
\hline \multirow[t]{2}{*}{ HRG-positive } & Treatment $=\mathrm{E}$ & $14(93)$ & $1.63(0.78-1.82)$ & & & \\
\hline & Treatment $=\mathrm{S}+\mathrm{E}$ & $23(87)$ & $1.86(1.70-3.66)$ & $0.35(0.16-0.76)$ & .008 & .010 \\
\hline \multirow[t]{2}{*}{ HRG-negative } & Treatment $=\mathrm{E}$ & $12(92)$ & $2.31(1.40-3.93)$ & & & \\
\hline & Treatment $=\mathrm{S}+\mathrm{E}$ & $20(95)$ & $1.64(1.15-1.77)$ & $2.15(0.97-4.76)$ & .059 & .052 \\
\hline
\end{tabular}

Note: Biomarker analyses were conducted for HRG mRNA expression by RNA-in situ hybridization measured on pretreatment biopsies in 69 patients (43 in the treatment arm and 26 in the control arm).

${ }^{a}$ Hazard ratio is defined for S+E vs. E or HRG positive vs. HRG negative.

Abbreviations: $\mathrm{Cl}$, confidence interval; $\mathrm{E}$, erlotinib arm; HRG, heregulin; PFS, progression-free survival; S+E, seribantumab + erlotinib arm.

through the MAPK and PI3K/Akt pathways. In addition, both HER3 and HRG are associated with impaired responses to both cytotoxic and targeted therapies [14, 15]. The activation of the ErbB3 pathway leads to multiple changes in tumor cells, resulting in a more aggressive and treatment-insensitive phenotype [2, 16-20]. In the control arm (patients treated with erlotinib alone), HRG-positive tumors appeared more aggressive and less responsive to treatment than HRG-negative (HR,
3.07; 95\% Cl, 1.19-7.91). Similar results were reported previously ovarian cancer and breast cancer where patients with HRG-positive tumors were insensitive to paclitaxel and exemestane, respectively [5].

Assessing the patient-specific ErbB3 network may be useful to select patients likely to benefit from seribantumab. Based on computational modeling of the ErbB network, HRG, ErbB3, HER2, EGFR, and BTC [5] were hypothesized to be the 
markers most predictive of seribantumab-mediated clinical benefit. Two separate randomized phase II trials in metastatic carcinoma highlighted HRG as the key biomarker for seribantumab activity. In a phase II randomized study of paclitaxel \pm seribantumab in platinum-resistant/refractory ovarian cancer, a biomarker-positive subpopulation was identified who appeared to benefit from the addition of seribantumab, based on high HRG RNA-ISH and low HER2 in pretreatment biopsies. HRG RNA-ISH showed the strongest predictive power of seribantumab clinical benefit, when compared with the other biomarkers examined, and established an optimal cutoff of HRG mRNA levels as $>10 \%$ cancer cells with at least 1+ HRG, which is defined as having 1-3 dots per cell [10]. Similarly, in a phase II randomized study of exemestane/placebo versus exemestane/seribantumab in estrogen receptor/progesterone receptor positive (ER/PR+), HER2-negative metastatic breast cancer, a treatment-sensitive biomarker-positive subpopulation was identified based on high HRG mRNA levels in archived tissue samples [21]. Given the evolving data seen in the other trials, the biomarker analysis from this trial focused solely on HRG, using the same criteria for HRG positivity. Patients with NSCLC with HRGpositive tumors appeared to benefit from the addition of seribantumab (HR, 0.37; 95\% Cl, 0.18-0.76, $p=.007$ ) whereas patients with HRG-negative tumors did not (HR, 2.15; 95\% $\mathrm{Cl}$ 0.97-4.76, $p=.059$ ), again consistent with the previous report in ovarian cancer. Disease control rates in the HRG-positive population were higher in the experimental treatment arm (39.1\%) compared with the control arm (7.1\%). However, in this small group of patients, OS was not significantly different for the two arms.

One interesting related observation is that patients with HRG-negative tumors had a higher risk of progression on the experimental arm relative to control ( $H R, 2.15 ; p=.059)$. This finding is consistent with the prior ovarian cancer study in which biomarker-negative patients (HRG-negative and HER2-positive) progressed faster when treated with seribantumab in combination with paclitaxel as compared with paclitaxel alone ( $\mathrm{HR}, 1.8 ; p=.023)$. It is also consistent with findings in patients with breast cancer with HRG-negative ER/PR+ HER-2-negative tumors that showed shortened PFS with the addition of seribantumab to exemestane (HR, 0.26; $p=.003)$. This finding is not unique to targeting ErbB3 signaling nor specific to seribantumab; similar effects have been observed with several other receptor tyrosine kinase inhibitors, including the anti-insulin-like growth factor-1 receptor antibodies figitumumab [22] and dalotuzumab [23] the antiEGFR antibodies cetuximab [24] and panitumumab [19], the anti-Met antibody onartuzumab [20], and the anti-HER2/ ErbB3 antibody pertuzumab [25]. The mechanisms of this therapy-mediated accelerated progression, which appear when the targeted pathway is inactive, remain unknown. Hypothetical mechanisms include (a) antagonistic antibodies exhibiting weak agonistic activities, (b) triggering of compensatory mechanisms, (c) affecting tumor microenvironment in a prosurvival direction. Whether any of these mechanisms occurs with ErbB3 inhibitors remains to be determined.

Overall safety data from our trial show that the combination of seribantumab and erlotinib is well tolerated. The most frequently reported treatment-emergent adverse events were diarrhea (69\%), rash (54\%), decreased appetite (44\%), fatigue (37\%), and nausea (34\%). When combined with clinical trial data from ovarian cancer (with paclitaxel) and patients with breast cancer (with exemestane), these safety data suggest that seribantumab should be well tolerated when combined with other established antineoplastic agents.

The goal of this study was to show that disruption of the HRG-autocrine loop by seribantumab-mediated blocking of HRG binding and disruption of HER2/HER3 dimerization could restore sensitivity to erlotinib. A shortfall of the study was that erlotinib has little single-agent activity in EGFR wild-type tumors. At the time this study was designed, erlotinib was approved as a second-line therapy for all NSCLC tumors, including EGFR wild-type and squamous histology. It was widely used for that indication, but activity was modest, with response rates of $9 \%$ and median PFS of 2.2 months [26]. Another limitation of this study is that the biomarker tested population ( $n=69$ ) was significantly smaller than the ITT population ( $n=129$ ), decreasing the power of the biomarker analysis. This concern is mitigated by the large effect size of the addition of seribantumab to erlotinib in the HRG-positive patient population, which was sufficient to yield a significant result.

\section{Conclusion}

Seribantumab did not improve outcomes when combined with erlotinib inpatients with EGFR wild-type NSCLC. However, among a predefined retrospective subgroup with high HRG mRNA levels assessed by RNA-ISH, the combination of seribantumab and erlotinib appeared to improve PFS, consistent with data seen in ovarian and breast cancer trials. As a result of these data, a prospective, randomized, open-label, international, multicenter phase II study of seribantumab, in combination with docetaxel, in patients with HRG-positive advanced adenocarcinoma, is underway (NCT02387216).

\section{Acknowledgments}

We thank Dr. Alena Zalutskaya and Michael Slater for critical discussion and review of the manuscript. This trial was funded by Merrimack Pharmaceuticals, Inc. Merrimack Pharmaceuticals had roles in the study design; collection, analysis, and interpretation of data; writing of the report and decision to submit paper for publication. The corresponding author had full access to all the data in the study and had final responsibility for the decision to submit for publication.

\section{Author Contributions}

Conception/design: Lecia V. Sequist, Bambang Adiwijaya, Geoffrey Kuesters, Walid S. Kamoun, Karen Andreas, J. Marc Pipas, Sergio Santillana

Provision of study material or patients: Lecia V. Sequist, Jhanelle Elaine Gray, Wael A. Harb, Ariel Lopez-Chavez, Robert C. Doebele, Manuel R. Modiano, David Michael Jackman, Maria Quintos Baggstrom, Akin Atmaca, Enriqueta Felip, Mariano Provencio, Manuel Cobo, Byoung Chul Cho, Keunchil Park, Frances A. Shepherd

Collection and/or assembly of data: Lecia V. Sequist, Jhanelle Elaine Gray, Wael A. Harb, Ariel Lopez-Chavez, Robert C. Doebele, Manuel R. Modiano, David Michael Jackman, Maria Quintos Baggstrom, Akin Atmaca, Enriqueta Felip, Mariano Provencio, Manuel Cobo, Bambang Adiwijaya, Geoffrey Kuesters, Walid S. Kamoun, Karen Andreas, J. Marc Pipas, Sergio Santillana, Byoung Chul Cho, Keunchil Park, Frances A. Shepherd 
Data analysis and interpretation: Lecia V. Sequist, Jhanelle Elaine Gray, Wael A. Harb, Ariel Lopez-Chavez, Robert C. Doebele, Manuel R. Modiano, David Michael Jackman, Maria Quintos Baggstrom, Akin Atmaca, Enriqueta Felip, Mariano Provencio, Manuel Cobo, Bambang Adiwijaya, Geoffrey Kuesters, Walid S. Kamoun, Karen Andreas, J. Marc Pipas, Sergio Santillana, Byoung Chul Cho, Keunchil Park, Frances A. Shepherd

Manuscript writing: Lecia V. Sequist, Bambang Adiwijaya, Geoffrey Kuesters, Walid S. Kamoun, J. Marc Pipas, Sergio Santillana, Frances A. Shepherd

Final approval of manuscript: Lecia V. Sequist, Jhanelle Elaine Gray, Wael A. Harb, Ariel Lopez-Chavez, Robert C. Doebele, Manuel R. Modiano, David Michael Jackman, Maria Quintos Baggstrom, Akin Atmaca, Enriqueta Felip, Mariano Provencio, Manuel Cobo, Bambang Adiwijaya, Geoffrey Kuesters, Walid S. Kamoun, Karen Andreas, J. Marc Pipas, Sergio Santillana, Byoung Chul Cho, Keunchil Park, Frances A. Shepherd

\section{Disclosures}

Lecia V. Sequist: AstraZeneca, Genentech, Pfizer, Blueprint Medicines, Merrimack Pharmaceuticals, Bristol-Myers Squibb, Novartis, Boehringer Ingelheim (C/A); Jhanelle Elaine Gray: Merck, Genentech, AstraZeneca, Bristol-Myers Squibb,
Boehringer Ingelheim, Array (RF), AstraZeneca, Celgene (C/A); Ariel Lopez-Chavez: Genentech/Roche (E); Robert C. Doebele: AstraZeneca, Takeda, Ignyta, Roche, Genentech, Bayer (C/A), Ignyta (RF), Abbott Molecular, Ignyta, Rain Therapeutics (IF), Rain Therapeutics (SAB, OI); Maria Quintos Baggstrom: Washington University, Cancer Research and Biostatistics Alliance Foundation (RF); Geoffrey Kuesters: Merrimack Pharmaceuticals (E); Walid S. Kamoun: Merrimack (E); Sergio Santillana: Merrimack Pharmaceuticals $(E, O I)$, Merimack Pharmaceuticals, Clarus/Blackstone Investments (C/A), Clarus Investments (other-external consultant), TAKEDA Pharmaceuticals (IP-patent coholder); Byoung Chul Cho: Norvatis, AstraZeneca, Boehringer-Ingelheim, Roche, BristolMyers Squibb, Ono, Yuhan, Eli Lilly \& Co, Janssen, Takeda, Merck Sharp \& Dohme (C/A), Norvatis (H), Norvartis, Bayer, AstraZeneca, MOGAM Institute, Dong-A ST, Champions Oncology, Janssen, Yuhan, Ono, Dizal Pharma, Merck Sharp \& Dohme (RF), TheraCanVac Inc. (OI). The other authors indicated no financial relationships.

(C/A) Consulting/advisory relationship; (RF) Research funding; (E) Employment; (ET) Expert testimony; (H) Honoraria received; (OI) Ownership interests; (IP) Intellectual property rights/inventor/patent holder; (SAB) Scientific advisory board

\section{REFERENCES}

1. Shroff GS, de Groot PM, Papadimitrakopoulou VA et al. Targeted therapy and immunotherapy in the treatment of non-small cell lung cancer. Radiol Clin North Am 2018;56: 485-95.

2. Ma J, Lyu $H$, Huang $J$ et al. Targeting of erbB3 receptor to overcome resistance in cancer treatment. Mol Cancer 2014;13:105.

3. Curley MD, Sabnis GJ, Wille L et al. Seribantumab, an Anti-ERBB3 antibody, delays the onset of resistance and restores sensitivity to letrozole in an estrogen receptor-positive breast cancer model. Mol Cancer Ther 2015; 14:2642-2652.

4. Mota JM, Collier KA, Barros Costa RL, et al. A comprehensive review of heregulins, HER3, and HER4 as potential therapeutic targets in cancer. Oncotarget 2017;8:89284-8930.

5. Schoeberl B, Kudla A, Masson $K$ et al. Systems biology driving drug development: From design to the clinical testing of the anti-ErbB3 antibody seribantumab (MM-121). NPJ Syst Biol Appl 2017;3:16034.

6. Kawakami H, Okamoto I, Yonesaka K et al. The anti-HER3 antibody patritumab abrogates cetuximab resistance mediated by heregulin in colorectal cancer cells. Oncotarget 2014;5: 11847-11856.

7. Mendell J, Freeman DJ, Feng $W$ et al. Clinical translation and validation of a predictive biomarker for patritumab, an anti-human epidermal growth factor receptor 3 (HER3) monoclonal antibody, in patients with advanced non-small cell lung cancer. EBioMedicine 2015;2:264-271.

8. Matthews S, Finn G, Kudla A et al. Identification of Heregulin (HRG) expression as a driver of a difficult-to-treat cancer phenotype and development of a companion diagnostic for the HRGErbB3 targeting drug seribantumab. Clin Cancer Res 2017;23:19a.

9. Sequist LV, Modiano M, Rixe $O$ et al. Targeting EGFR and ERBB3 in lung cancer patients: Clinical outcomes in a phase 1 trial of MM-121 in combination with erlotinib. J Clin Oncol 2012;307556a.

10. Liu JF, Ray-Coquard I, Selle F et al. Randomized phase II trial of seribantumab in combination with paclitaxel in patients with advanced platinum-resistant or -refractory ovarian cancer. J Clin Oncol 2016;34:4345-4353.

11. Sequist LV, Lopez-Chavez A, Doebele R et al. A randomized phase 2 trial of MM-121, a full human monoclonal antibody targeting ErbB3, in combination with erlotinib, in EGFR wild-type NSCLC patients. J Clin Oncol 2014;32:8051a.

12. Eisenhauer EA, Therasse $P$, Bogaerts J, et al. New response evaluation criteria in solid tumours: Revised RECIST guideline (version 1.1). Eur J Cancer 2009;45:228-247.

13. Higgins $M$, Doycle $C$, Paepke $S$ et al. A randomized, double-blind phase II trial of exemestane + MM-121, a monoclonal antibody targeting ErbB3, or placebo in postmenopausal women with locally advanced or metastatic ER+/PR+, Her2-negative breast cancer. J Clin Oncol 2014;32:587a.

14. Zhang N, Chang Y, Rios A et al. HER3/ErbB3, an emerging cancer therapeutic target. Acta Biochim Biophys Sin (Shanghai) 2016;48:39-48.

15. Esparis-Ogando A, Montero JC, Arribas J et al. Targeting the EGF/HER ligand-receptor system in cancer. Curr Pharm Des 2016;22:5887-5898.

16. Bezler M, Hengstler JG, Ullrich A. Inhibition of doxorubicin-induced HER3-PI3K-AKT signalling enhances apoptosis of ovarian cancer cells. Mol Oncol 2012;6:516-529.

17. Chakrabarty A, Sánchez V, Kuba MG et al. Feedback upregulation of HER3 (ErbB3) expression and activity attenuates antitumor effect of PI3K inhibitors. Proc Natl Acad Sci USA 2012; 109:2718-2723.

18. Hellyer NJ, Kim MS, Koland JG. Heregulindependent activation of phosphoinositide 3-kinase and Akt via the ErbB2/ErbB3 co-receptor. J Biol Chem 2001;276:42153-42161.
19. Douillard JY, Oliner KS, Siena $S$ et al. Panitumumab-FOLFOX4 treatment and RAS mutations in colorectal cancer. N Engl J Med 2013; 369:1023-1034.

20. Spigel DR, Ervin TJ, Ramlau RA, et al. Randomized phase II trial of Onartuzumab in combination with erlotinib in patients with advanced non-small-cell lung cancer. J Clin Oncol 2013; 31 (32): 4105-14.

21. Higgins MJ, Doyle C, Paepke $S$ et al. A randomized, double-blind phase II trial of exemestane plus MM-121 (a monoclonal antibody targeting ErbB3) or placebo in postmenopausal women with locally advanced or metastatic ER + /PR+, HER2-negative breast cancer. J Clin Oncol 2014;32(suppl):587a.

22. Langer $\mathrm{CJ}$, Novello $\mathrm{S}$, Park $\mathrm{K}$ et al. Randomized, phase III trial of first-line figitumumab in combination with paclitaxel and carboplatin versus paclitaxel and carboplatin alone in patients with advanced non-small-cell lung cancer. J Clin Oncol 2014;32:2059-2066.

23. Sclafani $F$, Kim TY, Cunningham D et al. A randomized phase II/III study of dalotuzumab in combination with cetuximab and irinotecan in chemorefractory, KRAS wild-type, metastatic colorectal cancer. J Natl Cancer Inst 2015;107:djv258.

24. Bokemeyer C, Van Cutsem E, Rougier P et al. Addition of cetuximab to chemotherapy as first-line treatment for KRAS wild-type metastatic colorectal cancer: Pooled analysis of the CRYSTAL and OPUS randomised clinical trials. Eur J Cancer 2012;48:1466-1475.

25. Makhija S, Amler LC, Glenn D et al. Clinical activity of gemcitabine plus pertuzumab in platinum-resistant ovarian cancer, fallopian tube cancer, or primary peritoneal cancer. J Clin Oncol 2010;28:1215-1223.

26. Shepherd FA, Rodrigues Pereira J, Ciuleanu $T$ et al. Erlotinib in previously treated non-small-cell lung cancer. N Engl J Med 2005;353:123-132.

See http://www.TheOncologist.com for supplemental material available online. 